\title{
Sastra Pesantren dalam Lintasan Sejarah
}

\author{
Roni Tabroni \\ Program Studi Pendidikan Sejarah \\ STKIP Pangeran Dharma Kusuma Segeran Indramayu \\ tabroni2506@gmail.com
}

\begin{abstract}
This article discusses the literature of pesantren and the themes that surround it since the beginning of the emergence of this institution of traditional Islamic education in the 18th century until now. Pesantren literature is defined as a literature that talks about the habits of pesantren. In addition, pesantren literature can be defined as a literary work in which there is a psychological side of pesantren with a strong religious style. This research uses the historical method such as heuristicarchive research, and literature review-critics, interpretation and historiography to traces the beginning of the existence of pesantren literature at the beginning of its founding and the development of its themes up to now. This theory is then combined with the theory of identity to give identity to the works of pesantren literature since its emergence in the early 18 th century until which emerged today. In addition, this study uses literature study by selecting several literary works of pesantren to determine the identity and the themes contained in it. The results show that pesantren literature has lived and developed since the emergence of Tegalsari pesantren in Ponorogo in 1742. At the beginning of the emergence of pesantren is often used as the place of the poets to produce works. The theme of the story revolves around the archipelago, Middle East and India in Sufi / Sufism. Sufi values / Sufism will be the hallmark of pesantren literature from the beginning to appear until now. These themes then undergo development and expansion with the emergence of literary pesantren genre pop and subversive these days by still making the pesantren as the center of the story and the values of Sufism as the foundation.
\end{abstract}

Keywords: Literature, Pesantren, Identity, Religious.

\section{A. Pendahuluan}

\section{Sastra dan Pesantren}

Berbicara tentang sastra maka akan berhadapan dengan suatu karya tulis yang memiliki definisi yang beraneka. ${ }^{1}$ Di antara definisi-definisi tersebut akan

\footnotetext{
${ }^{1}$ Secara etimologi sastra berasal dari bahasa Sansekerta yang merupakan gabungan dari kata sas, yang berarti mengarahkan dan memberi petunjuk dan tra yang biasanya menunjukkan
} 
muncul sebuah kesimpulan yang mana sebuah karya tulis bisa dikelompokkan sebagai karya sastra apabila memenuhi unsur-unsur tertentu. ${ }^{2}$ Jenis karya sastra pun tidak memiliki wajah serupa. Novel, cerpen, puisi, dan drama adalah di antara jenisjenis karya sastra. Di masa sekarang jenis ini bertambah dengan semakin maraknya media sosial dan majunya teknologi. Selain jenis yang berdasarkan bentuk dan isinya, sastra juga dapat dibedakan berdasarkan tempat karya sastra itu berkembang dan hidup, seperti sastra pesantren. ${ }^{3}$ Kekhasan sastra pesantren yang membedakannya dengan sastra lain adalah karena kekuatan roh transenden yang khas pula (Hidayatullah, 2007a). ${ }^{4}$ Sementara itu, Abdurrahman Wahid dalam Sunyoto (2012) menekankan sastra pesantren dalam dua definisi, pertama karyakarya sastra yang mengeksplorasi kebiasaan-kebiasaan di pesantren dan kedua,

alat atau sarana. Jadi, sastra diartikan sebagai alat untuk mengajar atau memberi petunjuk, buku petunjuk atau pengajaran. Lihat A. Teeuw. Sastra dan Ilmu Sastra: Pengantar Teori Sastra (Jakarta: Dunia Pustaka Jaya, 1984) Hal. 22-23. Dalam tradisi Barat (Eropa) kata sastra diambil dari kata literature (bahasa Inggris), litterature (bahasa Prancis), literatur (bahasa Jerman) dan literatuur (bahasa Belanda). Semua kata tersebut berasal dari kata litteratura (bahasa Latin) yang berarti kata (tulisan atau letter). Secara istilah sastra dapat diartikan sebagai ungkapan pribadi manusia yang berupa pengalaman, pemikiran, perasaan, ide, semangat, keyakinan dalam suatu bentuk gambaran konkret yang membangkitkan pesona dengan alat bahasa. Lihat Sumardjo dan Saini. Apresiasi Kesusasteraan. (Jakarta: Gramedia, 1997) Hal. 3-4. Hal berbeda dikemukakan oleh Abrams, yang menambahkan unsur gejala sosial dalam karya sastra. Abrams mengatakan bahwa sastra adalah refleksi masyarakat. Lihat Abrams, A Glossary of Literature Terms. (New York: Holt, Rinehart and Winston, 1981) Hal. 178-179.

${ }^{2}$ Ada dua unsur dalam karya sastra; instrinsik dan ekstrinsik. Unsur intrinsik di antaranya adalah cerita, peristiwa, plot, penokohan, tema, latar, sudut pandang penceritaan, bahasa atau gaya bahasa. Lihat Nurgiyantoro. Teori Pengkajian Fiksi (Yogyakarta: UGM Press, 2009) Hal. 23. Sedangkan unsur ekstrinsik di antaranya adalah latar belakang kehidupan pengarang, keyakinan, dan pandangan hidup pengarang, adat istiadat yang berlaku saat itu, situasi politik, persoalan sejarah, ekonomi, pengetahuan agama dan lain-lain. Lihat Suroto. Teori dan Bimbingan Apresiasi Sastra Indonesia. (Jakarta: Erlangga, 1989) Hal. 138.

3 Atribut pesantren dalam sastra dapat dirujuk dari pengertian sastra pesantren yang dikemukakan Imron dalam Pahlevi yang menyatakan bahwa sastra pesantren adalah sastra keagamaan yang berpusat di pesantren. Lihat Pahlevi. Sastra dan Budaya Islam Nusantara, Dialektika Antarsistem Nilai (Yogyakarta: SMF Adab IAIN Sunan Kalijaga, 1998) serta pengertian yang dikemukakan Jamal D. Rahman yang menyatakan bahwa sastra pesantren salah satu definisinya adalah sastra yang hidup di pesantren. Lihat Jamal D. Rahman. 2008.

4 Kekhasan itu di antaranya; patuh kepada kiai, ikhlas, sederhana, dan mencintai ilmu pengetahuan. Hal-hal itulah yang kemudian menjadi identitas sastra pesantren. 
adanya corak psikologi pesantren dengan struktur agama (warna religius) yang kuat. $^{5}$

Keberadaan sastra di pesantren menjadi unik karena sejak berdirinya pesantren pertama di Nusantara, yaitu pesantren Tegalsari pada tahun 1742, sampai keberadaan pesantren sekarang, tidak ada yang namanya kurikulum sastra di pesantren. Atmosfer sastra muncul ketika pelajaran-pelajaran agama yang diajarkan di pesantren mewujud dalam syair yang kemudian dibaca bersama-sama. ${ }^{6}$ Hubungan unik sastra dan pesantren ini telah menarik kalangan peneliti untuk menjadikannya objek penelitian. ${ }^{7}$ Akan tetapi, kebanyakan penelitian tersebut lebih bersifat sinkronis sehingga memunculkan kekosongan-kekosongan penelitian atau research gap. Oleh karena itulah, penelitian ini berusaha untuk mengisi kekosongan penelitian tersebut dengan permasalahan yang akan diteliti adalah; pertama, bagaimana bentuk dan perkembangan awal sastra di pesantren. Kedua, bagaimana bentuk dan perkembangan sastra pesantren di masa kolonial. Ketiga, bagaimana bentuk dan perkembangan sastra pesantren di masa sekarang. Dari permasalahan tersebut penelitian ini berusaha melakukan kajian diakronis dengan metode sejarah dan metode kualitatif (kajian pustaka) untuk melihat dinamika bentuk dan perkembangan karya sastra pesantren dari awal berdirinya pesantren sampai sekarang dengan bantuan teori identitas. Tujuan akhirnya diharapkan akan dapat ditemukan identitas sastra pesantren dari awal kemunculan sampai sekarang.

\footnotetext{
${ }^{5}$ Bandingkan dengan pengertian sastra pesantren yang dikemukakan oleh Toha Machsum. Menurutnya, sastra pesantren adalah sastra yang diciptakan oleh kalangan pesantren, baik oleh santri maupun ustadz dengan bercirikan tradisi pesantren dan berbicara tentang keislaman serta kepesantrenan bercorak religius, pop, dan subversif. Lihat Toha Machsum. Identitas dalam Sastra Pesantren di Jawa Timur. 2013. Hal. 410.

${ }^{6}$ Keterangan ini bisa dilihat dari wawancara media Kompas dengan seorang penyair sekaligus anak kiai, Acep Zamzam Noor dengan judul sastra dan pesantren tahun 2008.

${ }^{7}$ Lihat penelitian Toha Machsum di Jurnal Pendidikan dan Kebudayaan yang berjudul "Identitas dalam Sastra Pesantren di Jawa Timur" yang terbit pada tahun 2013. Penelitian tersebut merupakan studi pustaka beberapa karya sastra yang dihasilkan santri di beberapa pesantren di Jawa Timur pada masa sekarang. Bandingkan dengan penelitian Ahmad Baso dalam Pesantren Studies. Penelitian tersebut memberikan sumbangsih data-data sastra dan sastrawan pesantren di awal berdirinya. Akan tetapi tidak melakukan kajian diakronis sehingga tidak tampak dinamika bentuk dan identitas sastra pesantren serta perkembangannya.
} 


\section{B. Metode Penelitian}

Penelitian "Sastra Pesantren dalam Lintas Sejarah" ini akan menggunakan metode penelitian sejarah. Adapun langkah-langkahnya adalah heuristik, kritik, interpretasi dan historiografi. Heuristik dalam penelitian ini dapat disimpulkan sebagai kegiatan mencari, menemukan dan memperoleh sumber-sumber ${ }^{8}$ yang berhubungan dengan bentuk dan perkembangan sastra pesantren mulai abad ke-18 sampai sekarang. Sumber dalam penelitian ini hanya dikerucutkan menjadi sumber tertulis saja. Setelah heuristik, maka langkah selanjutnya adalah melakukan kritik. Menurut Herlina (2011: 15), kritik adalah "tahapan/kegiatan meneliti sumber, informasi, jejak secara kritis, yang terdiri atas kritik eksternal dan kritik internal.”

Tahapan selanjutnya dalam metode sejarah adalah tahapan interpretasi. Interpretasi dilakukan setelah data yang kita kumpulkan dikritik, dikoroborasi dan menghasilkan fakta sejarah. Fakta-fakta sejarah inilah yang kemudian kita tafsirkan atau kita interpretasikan. Menurut Garaghan (1946: 321-330) ada lima jenis interpretasi, yaitu:

1. Interpretasi verbal

Interpretasi ini berkaitan dengan beberapa faktor, yaitu bahasa, perbendaharaan kata, tata bahasa, konteks dan terjemahan. Tugas interpretasi ini untuk menjelaskan arti kata-kata atau kalimat..

2. Interpretasi teknis

Interpretasi ini didasarkan pada dua pertimbangan, pertama yaitu tujuan penyusunan dokumen, dan kedua, bentuk tulisan persisnya. Seorang peneliti

\footnotetext{
${ }^{8}$ Bandingkan pengertian tersebut dengan pengertian yang dikemukakan Renier. Renier mengartikan heuristik sebagai teknik untuk mencari jejak-jejak sejarah. Lihat Renier. Metode dan Manfaat Ilmu Sejarah (terj.). (Yogyakarta: Pustaka Pelajar, 1997) Hal. 113 atau pengertian yang dikemukakan oleh Nina Herlina yang menyatakan bahwa heuristik adalah tahapan/kegiatan menemukan dan menghimpun sumber, informasi, dan jejak masa lampau. Lihat Nina Herlina. Metode Sejarah (Bandung: Satya Historika, 2011) Hal. 15.
} 
yang mencoba membuat interpretasi teknis, harus tahu secara persis tujuan suatu dokumen dibuat dan kapan serta di mana dokumen itu ditulis.

3. Interpretasi logis

Interpretasi ini didasarkan atas cara berpikir logis, artinya berdasarkan cara berpikir yang benar.

4. Interpretasi psikologis

Interpretasi psikologis adalah interpretasi tentang sebuah dokumen yang merupakan usaha untuk membacanya melalui kacamata si pembuat dokumen, untuk memperoleh sudut pandangnya. Faktor-faktor yang menimbulkan reaksi psikologis dalam diri seorang pengarang, antara lain: 1. Asal-usul, lingkungan, tempat hidup, pengalaman pribadi, 2. Pembentukan kultural, 3. Karakter, dan 4. Tujuan penulis. Interpretasi ini dalam penelitian berkaitan dengan dokumen-dokumen/karya-karya sastra yang dibuat oleh para sastrawan.

5. Interpretasi faktual

Interpretasi ini tidak didasarkan atas kata-katanya tetapi terhadap faktanya. Yang menjadi titik berat adalah membiarkan fakta berbicara sendiri, tanpa perlu membuat interpretasi macam-macam, sehingga interpretasi faktual bisa dikatakan mengatasi interpretasi lainnya. Interpretasi faktual adalah interpretasi yang banyak digunakan dalam penelitian ini. Hal ini dilakukan untuk menghindari subyektifitas penulis.

sedangkan menurut Herlina (2011: 36) ada dua macam interpretasi; analisis dan sintesis. Analisis berarti menguraikan dan sintesis berarti menyatukan. Analisis dan sintesis akan selalu digunakan ketika menemukan fakta-fakta sejarah.

Setelah dilakukan interpretasi maka langkah terakhir adalah historiografi. Historiografi adalah tahapan/kegiatan menyampaikan hasil-hasil rekonstruksi imaginatif masa lampau sesuai dengan jejak-jejaknya (Herlina, 2011: 16). Dengan kata lain, historiografi adalah tahapan penulisan. Ada tiga hal yang harus 
diperhatikan dalam tahapan ini yang mana juga menjadi titik tekan dalam penelitian ini.

1) Seleksi. Seleksi atas fakta-fakta, untaian fakta-fakta berdasarkan dua kriteria: relevansi peristiwa dan kelayakannya (Renier, 1997: 185-187). Dalam tahapan seleksi kita harus memilih manakah dari bukti-bukti yang dianggap sebagai peristiwa, yang keahadirannya bukan saja dianggap penting dan berkaitan tetapi juga dapat diperkirakan sebagai tonggak penentu dalam mata rantai proses? Mana pula yang dianggap kejadian yang berfungsi sebagai ilustrasi dari berlaku atu tidaknya suatu bentukan struktural? Dan mana pula buktibukti yang cukup sekadar diketahui saja tanpa memiliki nilai penting untuk peristiwa tersebut (Abdullah, 1984: 92).

2) Imajinasi. Imajinasi menurut Renier (1997: 202) adalah suatu proses psikologis yang tidak menyajikan suatu pengetahuan baru tetapi membawa kita kepada pengetahuan yang telah ada sebelumnya. Selain itu, teori atau konsep yang dipergunakan dapat membantu sejarawan dalam membatasi imajinasi yang dapat dipertanggungjawabkan (Herlina, 2011: 57).

3) Kronologi. Kronologi adalah menyusun peristiwa-peristiwa yang berarti dalam urutan waktu (Renier, 1997: 194). Kronologi menjadi penting karena penyusunan data sejarah akan menjadi masuk akal apabila menggunakan kronologi atau dalam periode-periode waktu (Gottschalk, 2015: 174).

Selain menggunakan metode sejarah, penelitian ini menggunakan metode kualitatif. Menurut Moleong (1995), metode kualitatif adalah prosedur penelitian yang menghasilkan data-data deskriptif berupa kata-kata tertulis. ${ }^{9}$ Metode kualitatif dalam penelitian ini menggunakan kajian pustaka. ${ }^{10}$ Objek yang digunakan adalah karya sastra pesantren yang mewakili masa-masa awal berdirinya pesantren atau

\footnotetext{
${ }^{9}$ Bandingkan dengan definisi metode kualitatif yang dijelaskan oleh Muhajir. Menurut Muhajir, metode kualitatif titik tekannya adalah data disajikan dalam bentuk verbal. Lihat Muhajir. Metode Penelitian Kualitatif. Edisi III. Yogyakarta: Rake Sarakin, 1996).

${ }^{10}$ Kajian pustaka dipilih dengan alasan objek penelitiannya adalah karya-karya sastra yang berbentuk buku atau pustaka yang mana lebih menitikberatkan pada gagasan atau pemikiran daripada uji empiris.
} 
abad ke-18 sampai abad ke-19, karya sastra pesantren yang muncul pada masa kolonial dan karya sastra pesantren yang muncul sekarang ini. Mengingat populasi yang sangat banyak, penelitian ini akan membatasi pada karya sastra yang berupa prosa dan puisi saja. Sampel penelitian yang digunakan adalah empat karya sastra pada masing-masing periode sehingga total sampelnya adalah 9 karya sastra pesantren.

Penelitian ini bermula dari permasalahan bentuk dan identitas sastra pesantren. Oleh karena itu, untuk menjawab permasalah tersebut dibutuhkan konsepkonsep identitas. Konsep identitas secara umum diartikan sebagai citra yang membedakan suatu individu atau kelompok dengan individu atau kelompok lainnya yang dibangun oleh individu atau kelompok tersebut serta dimodifikasi secara terusmenerus melalui interaksi dengan pihak-pihak lain (Machsun, 2013: 409). ${ }^{11}$ Dalam penelitian ini, citra apa yang dibangun oleh sastra pesantren untuk membedakan dirinya dengan sastra yang lainnya yang mana hal ini dapat diperoleh melalui interaksi dengan sastra yang lainnya.

\section{Hasil dan Pembahasan}

Cerita tentang sastra pesantren dimulai dari berdirinya pesantren Tegalsari pada tahun $1742 .^{12}$ Pada masa itu pesantren telah menjadi tempat para pujangga

\footnotetext{
${ }^{11}$ Bandingkan dengan pengertian identitas (sosial) yang dikemukakan oleh Burke dan Stets. Menurut mereka, identitas sosial adalah kategorisasi diri dalam hal kelompok dan lebih terfokus pada makna terkait dalam menjadi anggota kategori sosial. Lihat Burke dan Stets. Trust and Commitment in an Identity Verification Context. Conference on Theory and Research on Group Processes. (Toronto 1997).

${ }^{12}$ Mengenai kesimpulan bahwa pesantren tertua di Nusantara adalah pesantren Tegalsari lihat Martin Van Bruinessen. Kitab Kuning, Pesantren dan Tarekat (Gading, 2012) Hal. 93. Hal ini berbeda dengan fakta bahwa Pangeran Diponegoro yang hidup di abad ke-16 pernah mesantren di pesantren Mlangi Yogyakarta di bawah asuhan Kiai Taptanjani. Lihat Peter Carey. 1986. Hal. 59. Ditambah fakta bahwa telah muncul pula pada pertengahan abad ke-15 seorang alim ulama yang pandai bermusik dan menyerat suluk. Orang tersebut kemudian dikenal sebagai Sunan Bonang, putra Sunan Ampel dan Nyai Ageng Manila dan pada abad ke-16 telah muncul Syekh Mutamakin dengan kitab Asyul Muwahidinnya.
} 
menghasilkan karya sastra. Pujangga keraton, seperti Yasadipura $\mathrm{I}^{13}$, Yasadipura II dan Ranggawarsita adalah di antara santri pesantren yang tekun mengembangkan karya sastra dalam bentuk kakawin, serat dan babad. Sumber inspirasi mereka bukan hanya kitab kuning melainkan juga pengalaman sejarah bangsa sendiri sebagaimana dialami oleh kerajaan Hindu, Budha, dan zaman Wali Sanga (Baso, 2012: 165).

Ciri khas dari kesastraan pesantren abad ini adalah pengadaptasian karyakarya yang berupa cerita rakyat Nusantara, Timur Tengah ataupun India menjadi cita rasa Islam Nusantara. Pengadaptasian ini mempunyai tujuan sosial-keagamaan. Karya sastra pesantren yang akan diteliti untuk mewakili abad ini adalah; Serat Cebolek, Serat Sasanasunu, dan Serat Kalatida. Karya-karya sastra tersebut adalah karya sastra kaum santri sejak abad ke-17 sampai abad ke-19 yang diproduksi dan beredar di kalangan santri pesisir utara Jawa.

Fungsi sosial-keagamaan sastra pesantren abad ini terlihat dalam Serat Cebolek. Serat Cebolek memperlihatkan bagaimana ajaran mistik dengan ajaran moral saling berjalinan dengan serasi (Soebardi, 1975: 47). Secara garis besar, Serat Cebolek terdiri dari dua bagian. Bagian pertama bercerita tentang perdebatan yang terjadi antara H. Pinang, penghulu Batang dengan K.H. A. Rifa'i dan bagian kedua bercerita tentang perdebatan antara Kiai Khotib Anom dengan Syekh Ahmad AlMutamakin dari Cebolek. Dalam Serat Cebolek Yasadipura I menggambarkan seorang ulama dari Kudus yang menunjukkan keahliannya dalam membaca dan menafsirkan naskah Jawa Kuno di hadapan para priyayi Keraton Surakarta (ulama birokrat). Cakupan bacaan sang tokoh begitu luas, mulai dari naskah Jawa Kuno, Serat Dewaruci hingga Suluk Malang Sumirang (Baso, 2012: 166). Ulama tersebut kemudian dikenal sebagai Kiai Khotib Anom. Perdebatan di antara mereka disebabkan oleh perbedaan pendapat tentang ilmu hakikat dan ilmu syari'at. Syekh Ahmad Al-Mutamakin yang mengajarkan ilmu hakikat pada khalayak ramai

\footnotetext{
13 Yosodipura I dikenal sebagai pembaharu sastra Jawa Kuno. Pada masanya karya-karya Jawa Kuno digubah kembali ke dalam bahasa Jawa Baru. Selain itu, Yasadipura I (wafat 1801) dikenal sebagai pujangga istana Keraton Surakarta yang pernah nyantri di sebuah pesantren di Kedu-Bagelen.
} 
kemudian diadili setelah Kiai Khotib Anom melaporkannya kepada pihak kerajaan karena menganggap ajaran Syekh Ahmad Al-Mutamakin adalah sesat. Dalam Serat Cebolek terlihat bagaimana ulama-ulama saat itu menjadi alat para penguasa untuk melanggengkan kekuasaannya. Hal ini kemudian mendapat perlawanan kultural dari Syekh Ahmad Al-Mutamakin.

Selain Serat Cebolek terdapat juga Serat Sasanasunu karya Yasadipura II. Serat ini menurut Pigeud, merupakan salah satu karya yang diciptakan pada zaman "rennaissance" kesusasteraan Jawa (1967: 7) ${ }^{14}$. Serat Sasanasunu adalah naskah Jawa Baru yang ditulis dengan menggunakan aksara dan bahasa Jawa dalam bentuk puisi Jawa macapat sepanjang 14 pupuh (canto) dengan jumlah bait sebanyak 493 . Naskah otograf diciptakan oleh Kyai Yasadipura II pada tahun 1819 (tahun Jawa 1747 dengan candrasengkala: Sapta Catur Swareng Janmi) (Wardhana, 2014: 151). Hal yang menonjol dari Serat Sasanasunu adalah adanya Ajaran Catur Budi. Ajaran Catur Budi dalam Serat Sasanasunu terdapat dalam pupuh (canto) X sinom, bait 26 s.d. 31. ${ }^{15}$ Berdasarkan teks dapat diambil kesimpulan bahwa ada empat kepribadian

\footnotetext{
${ }^{14}$ Serat ini oleh Poerbatjaraka dikelompokkan sebagai karya zaman Surakarta Awal. LIhat Poerbatjaraka (1957) Hal. 145-146.

${ }^{15}$ Bait 26: (Wardhana, 2014: 154)

yen wus amriyayi sira

Jikalau kamu sudah menjadi seorang priyayi,

nganggoa kawan prakawis pakailah empat macam

bubuden budi

awya tinilar

Keempat budi ini jangan kau tinggalkan,

kang dhingin budi priyayi yang pertama, ialah budi priyayi,

ping kalih budi santri yang kedua, budi santri,

budi sudagar ping telu yang ketiga, budi sudagar

budi tani kaping pat lire kang budi priyayi yang keempat budi petani. Yang dimaksud dengan budi priyayi,
} ialah tata karma, sopan satun sewaktu bicara 
untuk menjadi manusia ideal secara agama; Priyayi, santri, petani dan saudagar. Priyayi, santri, petani dan saudagar digunakan oleh Kyai Yasadipura II sebagai simbol atau lambang sifat-sifat perwatakan. Priyayi digunakan untuk menggambarkan orang yang beradab, tahu tata krama, sopan santun, baik dalam hal bicara, bertingkah laku maupun dalam berpakaian. Suka menolong, dapat menjadi pemimpin dan berpengetahuan luas serta berjiwa perwira. Santri digunakan untuk menggambarkan sifat-sifat perwatakan jujur, berhati suci, tidak suka menggunjing dan mempersoalkan perkara sepele, pemaaf, ikhlas dalam menerima kenyataan dan senantiasa bersyukur kepada Allah apapun yang di alami dan apapun yang menimpanya. Petani digunakan untuk menggambarkan sifat-sifat orang yang memiliki ketekunan, tidak gampang mengeluh, rajin, bersungguh-sungguh dalam bekerja, baik ringan ataupun yang berat. Tidak memiliki rasa iri hati, disiplin, tidak suka menunda-nunda pekerjaan, tidak sombong, berani menanggung resiko dan bertanggungjawab. Saudagar atau pedagang digunakan untuk melukiskan orang yang memiliki sifat penuh perhitungan, hemat, hati-hati, dalam melangkah senantiasa mempertimbangkan segala sesuatunya secara matang sisi untung-ruginya, dan risiko-risikonya (Wardhana, 2014: 156). Ajaran catur budi menunjukkan karya pesantren ini memiliki nilai sosial-keagamaan juga seperti Serat Cebolek karya Yasadipura I.

Terakhir, Serat Kalatidha karya Ranggawarsita. Karya ini berbentuk tembang macapat yang terdiri dari 12 syair. Kalatidha secara harfiah diartikan sebagai zaman edan. Syair Kalatidha dibagi menjadi tiga bagian: bagian pertama; bait 1 sampai 6, bagian kedua adalah bait 7 dan bagian ketiga; bait 8 sampai 12. Bagian pertama menjelaskan tentang masa ketika Ranggawarsita hidup tanpa prinsip. Bagian kedua bercerita tentang introspeksi diri. Bagian ketiga, terakhir, bercerita tentang sikap seseorang yang taat dengan agama di dalam masyarakat. Esensi atau amanat dari serta ini terdapat pada syair yang ketujuh; 


\begin{tabular}{|c|c|}
\hline Amenangi zaman édan, & Menyaksikan zaman gila, \\
\hline éwuhaya ing pambudi, & serba susah dalam bertindak, \\
\hline mélu ngédan nora tahan, & ikut gila tidak akan tahan, \\
\hline yén tan mélu anglakoni, & tapi kalau tidak mengikuti (gila), \\
\hline boya kéduman mélik, & bagaimana akan mendapatkan bagian, \\
\hline kaliren wekasanipun, & kelaparan pada akhirnya, \\
\hline ndilalah kersa Allah, & namun telah menjadi kehendak Allah, \\
\hline begja-begjaning kang lali, & sebahagia-bahagianya orang yang lalai, \\
\hline luwih begja kang éling klawan & akan lebih bahagia orang yang tetap \\
waspada. & ingat dan waspada. \\
\hline
\end{tabular}

Dari syair tersebut dapat diambil kesimpulan bagaimana Ranggawarsita menjadikan karya sastra sebagai pepeling/pengingat manusia akan adanya kehendak Allah. Dimensi percaya dan pasrah akan kehendak Allah menjadi ciri khas pesantren yang muncul dalam karya ini. Ketiga karya yang mewakili abad ini menunjukkan watak sastra pesantren yang lebih condong ke arah tasawuf/sufi dengan dibarengi fungsi sosial-keagamaan yang muncul tidak terlalu menonjol.

Pada akhir abad ke-19 dan awal abad ke-20 karya sastra pesantren masih berkisar pada cerita-cerita rakyat, dan juga cerita-cerita Timur Tengah dan India yang terus dimodifikasi sesuai dengan kebutuhan lokal Islam Nusantara. Selain itu, sastra pesantren pada masa ini masih tetap meneruskan watak sufi/tasawufnya dengan mendapat tambahan fungsi. Fungsi sosial-keagamaan tetap muncul tapi kemudian berpadu serasi dengan fungsi perlawanan terhadap kolonialisme Belanda dan perlawanan terhadap penetrasi kebudayaan Barat. Ada tiga karya sastra yang akan mewakili masa ini; Wawacan Panji Wulung karya Raden Mohammad Moesa (kepala penghulu Garut dan pernah nyantri di satu pesantren di Purwakarta), Pahlawan ti Pesantren (Pahlawan dari Pesantren) karya Ki Umbara (Wiredja 
Ranusulaksana) (1914-2004) dan S.A. Hikmat (Soeboer Abdoerrachman) (19181971) dan beberapa dangding karya Penghulu Haji Hassan Musthafa (1852-1930).

Pertama, Wawacan Panji Wulung. Wawacan ini bercerita tentang putra raja yang bernama Panji Wulung dari kerajaan Sokadana yang kemudian menjadi raja kerajaan Campa. Cerita berawal dari kelahiran seorang anak dari selir raja yang bernama Panji Wulung. Panji Wulung yang diasuh oleh patih karena ibunya berusaha dibunuh oleh sang ratu kemudian berkelana hingga ke Campa. Di sana Panji Wulung menikah dengan putri Kerajaan Campa dan kemudian menjadi raja setelah raja terakhir mangkat. Akhir cerita dihiasi dengan bersatunya kerajaan Sokadana dan Campa setelah raja Sokadana tahu bahwa Panji Wulung adalah anaknya. Wawacan Panji Wulung mengangkat sisi kemanusiaan dalam tokohtokohnya. Suatu nilai yang kemudian akan selalu diperjuangkan oleh sastra-sastra pesantren.

Kedua, karya sastra pesantren dapat dirujuk dari salah satu dangding karya Penghulu Haji Hassan Musthafa, seperti di bawah ini :

\section{"Heulanan kuring mundur deui}

Tacan tega ka barudak urang

Basana serab pangilo

Matak risi nu sisip budi

Geus tepi ka kitu

Dongkap ka masya Allahna

Kajeun teuing uleh hararemeng galih

Moal matak doraka"

Sementara saya mundur lagi

Tidak sampai hati kepada anak-anak

Kata mereka silau

Karena saya demikian 
Menyebabkan risau mereka yang berjiwa kecil

(Karena) budi-daya saya

Sudah sampai sedemikian

Sampai mereka mengatakan "masya Allah"

Biarlah (jangan peduli) jangan risau hati

(Karena) tidak akan menyebabkan (saya) berdosa.

Dari dangding di atas dapat ditarik kesimpulan bahwa unsur tasawuf dalam karya sastra pesantren masih mendominasi dan mencengkeram kuat sastra pesantren.

Terakhir, Pahlawan ti Pasantren (Pahlawan dari Pesantren) bercerita tentang perjuangan santri dalam menghadapi kolonialisme. Karya ini menjadi pendobrak dalam hal fungsi sastra pesantren sebagai gerbong perlawanan terhadap kolonialisme.

Pada separuh akhir abad ke-20 tradisi sastra pesantren mulai menggeliat hebat. Pada tahun 1960-an muncul nama Syu'bah Asa, Djamil Suherman dan Fudoli Zaini. Pada tahun 1970-an muncul Emha Ainun Nadjib (alumni Pesantren Gontor) dengan sajak-sajak sosial-religiusnya. Tahun 1980-an dan 1990-an muncul K.H. Mustofa Bisri (Gus Mus, Pengasuh Ponpes Raudlatuttolibin, Rembang), Jamal D Rahman, Acep Zamzam Noor (Putra mantan Rois Syuriyah PBNU, KH Ilyas Rukyat Tasikmalaya), Ahmad Syubbanuddin Alwy (putra kiai dari Cirebon), Abidah El-Khaliqy, Ahmad Tohari, Abdul Hadi WM, Zawawi Imron, Hamdi Salad, Nasruddin Anshory, Kuswaidi Syafi'ie dan lain-lain. Dan di era milenial ini muncul novelis Habiburrahman El-Shirazy. Meraka adalah sastrawan yang pernah belajar di pesantren dan karya-karya mereka pada umumnya bernafaskan nilai-nilai religius pesantren.

Pada penelitian ini, sampel yang akan digunakan untuk mewakili masa akhir abad ke-20 dan masa milenial adalah karya dari penyair Acep Zamzam Noor, Ahmad Tohari, dan Mustofa Bisri. Karya-karya mereka penuh dengan unsur ketauhidan yang berpadu dengan kritik yang lembut. Hal tersebut bisa dilihat dari 
puisi Mustofa Bisri (Gus Mus): Kalau Kau sibuk berzikir saja/ Kapan Kau sempat menyadari keagungan yang kau zikir?/ Kalau Kau sibuk dengan keagungan yang Kau zikiri saja/ Kapan Kau akan mengenalnya. Atau puisi Acep Zamzam Noor yang berjudul Rumah Yang Terbuka; Aku menggali cahaya dari kuburan-kuburan kenanganmu/ Untuk kunyalakan dalam jiwa/ Dengan kaki telanjang/ Kumasuki rumah batinmu yang terbuka/ Di lantai pualam aku bergulingan sepanjang malam. Sifat-sifat transenden dari karya-karya tersebut begitu terasa. Hal inilah yang yang melekat erat dalam tradisi pesantren sejak awal kemunculannya. ${ }^{16}$

Dalam tradisi prosa, watak atau identitas pesantren dapat dilihat dari sisi bagaimana nilai-nilai keadilan, kebenaran, kasih sayang, kemanusiaan diperjuangkan. Hal tersebut bisa dilihat dari Novel Ronggeng Dukuh Paruk karya Ahmad Tohari. Pembelaan sang pengarang terhadap mereka yang tidak secara langsung terlibat dengan PKI yang dianiaya dan mendapat kekerasan, menunjukkan pembelaan sang pengarang terhadap nilai-nilai kemanusiaan. Sebuah nilai yang merupakan amanat Tuhan untuk selalu diperjuangkan.

\section{Simpulan}

Dari lintasan sejarah dapat dilihat bahwa sastra pesantren dapat dirujuk keberadaannya sejak abad ke-15, keberadaan Sunan Bonang, sampai pada masa sekarang. Pada awal kemunculannya tema-tema sastra pesantren lebih banyak didominasi oleh tema-tema sufi atau tasawuf, seperti Serat Cebolek dan Serat

\footnotetext{
16 Bandingkan dengan Suluk Wujil, karya Sunan Bonang; Lalu apa pula zikir yang sebenarnya/ Dengar: walau siang malam berzikir/ Jika tidak dibimbing petunjuk Allah/ Zikirmu tidak sempurna/Zikir sejati tahu bagaimana/datang dan perginya nafs/ di situlah Yang Ada, memperlihatkan/ Hayat melalui yang empat.
} 
Sasanasunu. Tema-tema sufi yang berbalut dengan fungsi sosial-keagamaan masih terus muncul hingga sekarang yang mana dapat ditemukan pada karya-karya Mustofa Bisri, Acem Zamzam Noor maupun novelis Habiburahman El-Shirazy. Dapat disimpulkan bahwa ciri khas atau identitas sastra pesantren yang akan selalu ada adalah munculnya tema-tema tasawuf yang bersimfoni dengan indah bersama kritik sosial.

\section{DAFTAR PUSTAKA}

Abrams, M.H. 1981. A Glossary of Literature Terms. New York: Holt, Rinehart and Winston.

A, Teeuw. 1984. Sastra dan Ilmu Sastra: Pengantar Teori Sastra. Jakarta: Dunia. Pustaka Jaya.

Baso, Ahmad. 2012. Akar Pendidikan Kewarganegaraan di Pesantren. Jurnal Pendidikan Islam. Vol. XVII. No.2.

Burke, Peter J. and Jan E. Stets. 1997. "Trust and Commitment in an Identity Verification Context." Conference on Theory and Research on Group Processes. Toronto, August.

Garaghan, Gilbert J. 1946. A Guide to Historical Method. New York: Fordham University Press.

Gottschalk, Louis. 2015. Mengerti Sejarah (terj.). Jakarta: Yayasan Penerbit Universitas Indonesia.

Herlina, Nina. 2011. Metode Sejarah. Bandung: Satya Historika.

Hidayatullah, M. Irfan. 2007a. Pergulatan dalam Sastra Pesantren. Makalah pada acara diskusi 10. tahun FLP di Surabaya.

Machsum, Toha. 2013. Identity in the Literary Works of Pesantren in East Java. Jurnal Pendidikan dan Kebudayan. Vol. 19. Nomor 3.

Martin Van Bruinessen. 2012. Kitab Kuning, Pesantren dan Tarekat. Jakarta: Gading.

Moleong, Lexy J. 1995. Metode Penelitian Kualitatif. Bandung: Rosda Karya. 
Muhajir, Noeng. 1996. Metode Penelitian Kualitatif. Edisi III. Yogyakarta: Rake Sarakin.

Nurgiyantoro, Burhan. 2009. Teori Pengkajian Fiksi. Yogyakarta: Gadjah Mada University Press.

Pahlevi. 1998. Sastra dan Budaya Islam Nusantara, Dialektika Antarsistem Nilai. Yogyakarta: SMF Adab IAIN Sunan Kalijaga.

Pigeaud, Th. 1967. Litterature of Java. Jilid I dan II. Leiden: The Hague Martinus Nijhoff.

Poerbatjaraka, RM.Ng. 1957. Kapustakan Jawi. Jakarta: Djambatan

Renier, G.J. 1997. Metode dan Manfaat Ilmu Sejarah (terj.). Yogyakarta: Pustaka Pelajar.

Serat Sasanasunu, Naskah Nomor BG 253, Tahun Penyalinan 2 Februari 1856. Koleksi Perpustakaan RI.

S. Soebardi. 1975. The Book of Cebolek. The Hague-Martiinu Nijhaff.

Sumardjo, Jacob \& Saini K.M.1997. Apresiasi Kesusastraan. Jakarta: Gramedia.

Sunyoto, Agus. 2012. Atlas Wali Songo. Jakarta: Mizan.

Suroto. 1989. Teori dan Bimbingan Apresiasi Sastra Indonesia. Jakarta: Erlangga.

Tohari, Ahmad. 1982. Ronggeng Dukuh Paruk. Jakarta: Gramedia Pustaka Utama.

Wardhana, Chritiana Dwi. 2014. Ajaran Catur Budi dalam Serat Sasanasunu Karya Kyai Yasadipura II. Jurnal Jumantara Vol. 5 No.1 